\title{
Effect of Rumen Protected Amino Acids and Fish Meal on Feed Conversion Ratio of Murrah Buffalo Heifers
}

\author{
Ravi Kumar ${ }^{1 *}$, Dipankar Kar ${ }^{1}$, Deepak Kumar', Vikramjeet Singh ${ }^{2}$ and Sajjan Sihag ${ }^{3}$ \\ ${ }^{1}$ Department of Livestock Production Management, ${ }^{2}$ Department of Veterinary Physiology \\ and Biochemistry, ${ }^{3}$ Department of Animal Nutrition, Collage of Veterinary Sciences, LUVAS, \\ Hisar-125004, Haryana, India \\ *Corresponding author
}

\begin{tabular}{|l|}
\hline Ke y w o r d s \\
Rumen protected \\
amino acids, Fish \\
meal, FCR, Buffalo \\
heifers
\end{tabular}

\section{Introduction}

Provision of nutrients in balanced form and required amounts is essential to meet the productive targets in livestock. Among nutrients, protein plays a pivotal role in growth, production and reproduction of farm animals. However, nature and level of dietary protein determine the supply of both physiologically and dietary essential amino acids in animals. In ruminants, protein requirements are two fold; to support the anaerobic ecosystem in the rumen and to meet the animal needs. However, because of ruminal anaerobic fermentation, a portion of dietary protein is degraded in the rumen 
(RDP) and the rest escape from ruminal degradation (RUP). The RDP is used to support the growth of anaerobic bacteria and thus profile of microbial protein along with the nature of RUP determines the availability of dietary and physiologically essential amino acids in ruminants. Generally, the requirements of high producing animals for dietary essential amino acids are increased from those supplied by the microbial and escaped protein pool. Thus the dietary supplementation of rumen protected protein and amino acids are recommended to support the physiological and productive needs of livestock for amino acids (Ali et al., 2009). Protein supplement that are naturally high in rumen un-degradable protein, used mainly in ruminant diets is fish meal. Fish meal contains high levels of available Lysine and Methionine which are deficient in plant protein supplements (Lall, 1991). Fishmeal protein is high in biological value, provides twice the Lysine and four times the Methionine to the small intestine (Blauwiekel et al., 1992).

As we are aware of the importance of the buffalo, proper rearing of buffalo heifers as a future milk producer, which will eventually replace the old herd, so it is necessary to have better feeding management. But raising young heifer was one of the most often neglected jobs on the dairy farms. Unfortunately, in many part of India farmers considers buffalo heifer to be unproductive and hence they do not feed them properly. How a heifer develops into her potential for milk production depends upon how well we raise and manage her (Alam et al., 2012). Nutrition draws the greatest attention because lack of proper nutrition can reduce the reproductive efficiency. There is need to improve the animal production through better feeding and husbandry management at all stage of buffalo life especially at growing stage of heifers. Keeping in view the above facts, the present investigation was conducted to explore the effect of rumen protected Methionine, Lysine and fish meal supplementation on feed conversion ratio in Murrah buffalo heifers.

\section{Materials and Methods}

The present investigation was conducted at the Buffalo Research Center of Department of Livestock Production Management, College of Veterinary Sciences, Lala Lajpat Rai University of Veterinary and Animal Sciences, Hisar. Prior approval was taken to conduct the present investigation by the Institutional Animal Ethics Committee. Eighteen Murrah buffalo heifers of nearly same age and body weight were randomly distributed into three treatment groups each having six buffalo heifers following Completely Randomized Design (CRD) in such a manner that average body weight and age of each experimental group was almost similar. The initial average body weight of buffalo heifers in three treatment groups were 224.33, 223.83 and $223.33 \mathrm{~kg}$, respectively and differences in initial body weight were non-significant. The details of different treatments are presented in table 1 .

During the experimental period, the animals were given green fodder and concentrate mixture to meet their protein and energy need for growth as per ICAR (Ranjhan, 1998) feeding standard. The amount of concentrate mixture was given to each group in such a way that the experimental ration remains isoproteinaceous. The quantity of different feeds given to each group was adjusted at fortnightly intervals so that the overall DCP requirements of heifers were met according to the change in body weight. Animals were given ad lib fresh water throughout the experimental period. Before formulation of rations, the feed ingredients were analyzed (AOAC, 2005) for proximate composition (Table 2). Based upon the proximate composition of feed ingredients, the ration for the different experimental groups of animals 
was formulated. The composition of the experimental diet of different treatment groups and proximate chemical composition is presented in (Table 3).

\section{Observation recorded}

\section{Feed intake}

All the animals were fed roughage and concentrate individually. The animals were given weighted quantity of feed and fodder daily as per computed ration. Daily feed intake during the experimental period was determined on the basis of feeds and fodder offered and left over and data were compiled on fortnightly basis.

\section{Body weight gain}

Experimental animals were weighted (kg) just before starting the actual experiment and thereafter at fortnightly intervals using standard platform weighing balance (Avery, capacity $1000 \mathrm{~kg}$ ). The body weights were recorded in the morning before providing any water or feed to the animals. These body weights were used for determining the growth rate and also for the purpose of the computing the ration for the animals.

\section{Feed conversion ratio (FCR)}

On the basis of feed and fodder consumption, dry matter (DM) consumed by the animals were estimated. For the calculation of FCR, feed intake per $\mathrm{kg}$ body weight gain was calculated.

\section{Statistical analysis}

The data were analyzed statistically using standard methods (Snedecor and Cochran, 1994). The data were expressed as Mean \pm SE and were analyzed by one-way ANOVA using general linear model of SPSS version 20 and Duncan's multiple range tests was applied to test the significance. Significance was declared when $\mathrm{P}$ value is less than 0.05 (Duncan, 1955).

\section{Results and Discussion}

\section{Dry matter intake (kg/day)}

Mean daily dry matter intakes $(\mathrm{kg} / \mathrm{d})$ during the experimental period are given in table 4 and with Figure 1. Overall DMI after 90 days was found to be $6.99,7.04$ and $7.02 \mathrm{~kg}$ /day in $\mathrm{T}_{1}, \mathrm{~T}_{2}$ and $\mathrm{T}_{3}$ respectively. Statistical analysis of data revealed that there was no significant difference in the dry matter intake among the different treatments.

Socha et al., (2005), Lara et al., (2006) and Lee et al., (2012) observed that there was no effect of Lysine and Methionine supplementation on DM intake $\mathrm{kg} / \mathrm{d}$ in dairy cows. Ahmed et al., (2016) also reported no significant difference for DMI between control and treatment groups fed Lysine and Methionine supplemented ration in Nili-Ravi buffaloes. Also, Gajera et al., (2013) witnessed the similar results in Jaffrabadi buffalo heifers. Similarly, Sai et al., (2014) repoted no differences in average DM intake by supplementation of bypass Methionine and Lysine in the ration of crossbred calves.

Findings of Hussein and Jordan (1991) in growing finishing lambs and Davenport et al., (1990) in crossbred beef calves reveal similar results i.e. feeding fish meal as a source of protected amino acids did not show any improvement in DMI.

\section{Average daily gain (ADG)}

Average daily weight gain (g/day) by growing Murrah buffalo heifers under different treatments has been presented in table 5 and with Figure 2. After first fifteen days average daily weight gain were 622.22, 677.78 and $666.67 \mathrm{~g} / \mathrm{d}$ in $\mathrm{T}_{1}, \mathrm{~T}_{2}$ and $\mathrm{T}_{3}$, respectively. 
Table.1 Details of different treatments

\begin{tabular}{|c|c|c|}
\hline S. No. & Group & Treatment \\
\hline 1. & $\mathbf{T}_{1}$ (Control) & Seasonal green fodder + wheat straw + conventional concentrate mixture \\
\hline 2. & $\mathbf{T}_{2}$ & $\begin{array}{l}\text { Seasonal green fodder }+ \text { wheat straw }+ \text { conventional concentrate mixture } \\
+ \text { fish meal }\end{array}$ \\
\hline 3. & $\mathbf{T}_{\mathbf{3}}$ & $\begin{array}{l}\text { Seasonal green fodder }+ \text { wheat straw }+ \text { conventional concentrate mixture } \\
+10 \mathrm{~g} \text { commercial bypass Lysine per animal per day }+2 \mathrm{~g} \text { commercial } \\
\text { bypass Methionine per animal per day }\end{array}$ \\
\hline
\end{tabular}

Table. 2 Chemical analysis of feed ingredients (on DM basis)

\begin{tabular}{|l|}
\hline Ingredients \\
\hline Wheat straw \\
\hline Green sorghum \\
\hline Wheat \\
\hline Barley \\
\hline Groundnut cake (GNC) \\
\hline Mustard cake \\
\hline Fish meal \\
\hline Wheat bran \\
\hline
\end{tabular}

\begin{tabular}{|c|c|c|c|c|c|c|}
\hline DM & CP & CF & EE & Ash & OM & NFE \\
\hline 94.27 & 1.78 & 35.31 & 1.04 & 12.49 & 87.51 & 49.38 \\
\hline 24.92 & 7.45 & 26.82 & 3.4 & 10.7 & 90.3 & 51.63 \\
\hline 91.61 & 10.89 & 2.77 & 3.15 & 2.23 & 97.77 & 80.96 \\
\hline 93.32 & 9.55 & 7.88 & 1.74 & 4.96 & 95.04 & 75.87 \\
\hline 93.47 & 40.23 & 9.43 & 9.05 & 8.9 & 91.1 & 32.39 \\
\hline 93.46 & 35.62 & 8.33 & 6.25 & 6.83 & 93.17 & 42.97 \\
\hline 89.97 & 45.8 & 1.81 & 11.4 & 27.07 & 72.93 & 13.92 \\
\hline 92.86 & 13.86 & 11.83 & 1.01 & 4.12 & 95.88 & 69.18 \\
\hline
\end{tabular}

Table.3 Ingredients of concentrate mixture $(\mathrm{kg})$ and its chemical composition (on DM basis)

\begin{tabular}{|c|c|c|c|c|}
\hline Sr. no. & Ingredient & $\mathrm{T}_{1}(\mathrm{~kg})$ & $\mathrm{T}_{2}(\mathrm{~kg})$ & $\mathrm{T}_{3}(\mathrm{~kg})$ \\
\hline 1. & Barley & 25 & 25 & 25 \\
\hline 2. & Wheat & 10 & 12 & 10 \\
\hline 3. & Ground Nut Cake & 20 & 13 & 20 \\
\hline 4. & Mustard Cake & 10 & 10 & 10 \\
\hline 5. & Wheat Bran & 32 & 33.5 & 32 \\
\hline 6. & Fish Meal & 0 & 3.5 & 0 \\
\hline 7. & Bypass Methionine & 0 & 0 & $*$ \\
\hline 8. & Bypass Lysine & 0 & 0 & $* *$ \\
\hline 9. & Mineral Mixture & 2 & 2 & 2 \\
\hline \multirow[t]{2}{*}{10.} & Salt & 1 & 1 & 1 \\
\hline & Total & 100 & 100 & 100 \\
\hline \multicolumn{5}{|c|}{$\begin{array}{l}\text { * supplemented @ } 2 \mathrm{~g} / \text { animal/day } \\
* * \text { supplemented @ } 10 \mathrm{~g} / \text { animal/day } \\
\end{array}$} \\
\hline \multicolumn{5}{|c|}{ Chemical composition (\% DM basis) } \\
\hline 1. & Dry matter $(\mathrm{DM})$ & 90.46 & 90.17 & 90.67 \\
\hline 2. & Crude protein $(\mathrm{CP})$ & 24.51 & 24.88 & 24.66 \\
\hline 3. & Crude fiber $(\mathrm{CF})$ & 6.31 & 6.49 & 6.12 \\
\hline 4. & Ether extract (EE) & 5.07 & 5.02 & 5.59 \\
\hline 5. & Ash & 7.41 & 7.77 & 7.91 \\
\hline 6. & Organic matter (OM) & 92.59 & 92.23 & 92.09 \\
\hline 7. & NFE & 55.70 & 55.84 & 55.72 \\
\hline
\end{tabular}


Table.4 Average dry matter intake (kg/day) of experimental Murrah heifers at fortnightly intervals
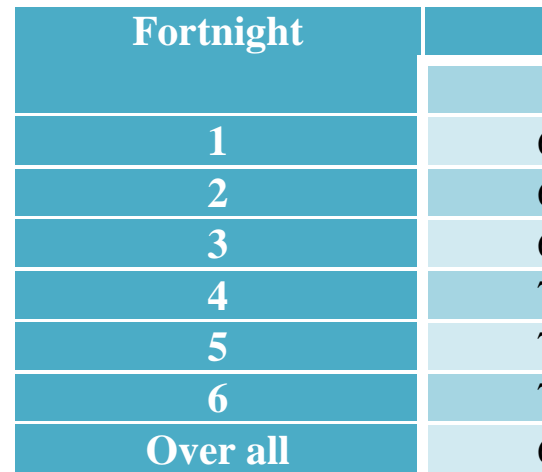

\begin{tabular}{|c|c|c|}
\hline $\mathbf{T}_{1}$ & $\mathbf{T}_{2}$ & $\mathbf{T}_{3}$ \\
\hline $6.09 \pm 0.02$ & $6.12 \pm 0.04$ & $6.13 \pm 0.06$ \\
\hline $6.34 \pm 0.04$ & $6.36 \pm 0.04$ & $6.35 \pm 0.04$ \\
\hline $6.82 \pm 0.06$ & $6.84 \pm 0.06$ & $6.83 \pm 0.06$ \\
\hline $7.13 \pm 0.10$ & $7.19 \pm 0.06$ & $7.17 \pm 0.09$ \\
\hline $7.67 \pm 0.05$ & $7.79 \pm 0.02$ & $7.76 \pm 0.07$ \\
\hline $7.89 \pm 0.05$ & $7.95 \pm 0.06$ & $7.92 \pm 0.03$ \\
\hline $6.99 \pm 0.11$ & $7.04 \pm 0.11$ & $7.02 \pm 0.11$ \\
\hline
\end{tabular}

Values are means \pm standard errors

Table.5 Average daily body weight gain (g) of experimental Murrah buffalo heifers at fortnightly intervals

\begin{tabular}{|c|c|c|c|}
\hline \multirow{2}{*}{ Fortnight } & \multicolumn{3}{|c|}{ Treatments } \\
\hline & $\mathbf{T}_{\mathbf{1}}$ & $\mathbf{T}_{\mathbf{2}}$ & $\mathbf{T}_{\mathbf{3}}$ \\
\hline 1 & $622.22 \pm 88.89$ & $677.78 \pm 150.47$ & $666.67 \pm 62.06$ \\
\hline 2 & $644.44 \pm 99.88$ & $733.33 \pm 66.67$ & $788.89 \pm 58.16$ \\
\hline 3 & $744.44 \pm 52.82$ & $800.00 \pm 51.64$ & $788.89 \pm 31.82$ \\
\hline 4 & $655.56^{\mathrm{b}} \pm 52.82$ & $811.11^{\mathrm{a}} \pm 40.06$ & $777.78^{\mathrm{ab}} \pm 37.18$ \\
\hline 5 & $666.67^{\mathrm{b}} \pm 45.54$ & $833.33^{\mathrm{a}} \pm 50.52$ & $788.89^{\mathrm{ab}} \pm 43.60$ \\
\hline 6 & $677.78^{\mathrm{b}} \pm 40.06$ & $844.44^{\mathrm{a}} \pm 32.96$ & $777.78^{\mathrm{ab}} \pm 32.96$ \\
\hline Over all & $668.51^{\mathrm{b}} \pm 26.22$ & $783.33^{\mathrm{a}} \pm 30.55$ & $764.81^{\mathrm{a}} \pm 18.87$ \\
\hline
\end{tabular}

Values are means \pm standard errors

The means in a row with different superscripts differ significantly between the treatments $(\mathrm{P}<0.05)$

Table.6 Mean feed conversion ratio (DMI/kg body weight gain) of experimental Murrah heifers at fortnightly interval

\begin{tabular}{|c|c|c|c|}
\hline \multirow{2}{*}{ Fortnight } & \multicolumn{3}{|c|}{ Treatments } \\
\cline { 2 - 4 } & $\mathbf{T}_{\mathbf{1}}$ & $\mathbf{T}_{\mathbf{2}}$ & $\mathbf{T}_{\mathbf{3}}$ \\
\hline $\mathbf{1}$ & $10.86 \pm 1.53$ & $10.86 \pm 1.53$ & $9.63 \pm 0.96$ \\
\hline 2 & $11.06 \pm 1.67$ & $9.09 \pm 0.94$ & $8.35 \pm 0.80$ \\
\hline 3 & $9.38 \pm 0.62$ & $8.72 \pm 0.56$ & $8.74 \pm 0.42$ \\
\hline 4 & $11.17^{\mathrm{a}} \pm 0.77$ & $8.98^{\mathrm{b}} \pm 0.46$ & $9.29^{\mathrm{b}} \pm 0.33$ \\
\hline 5 & $11.75^{\mathrm{a}} \pm 0.72$ & $9.41^{\mathrm{b}} \pm 0.53$ & $9.88^{\mathrm{b}} \pm 0.53$ \\
\hline 6 & $11.83^{\mathrm{a}} \pm 0.68$ & $9.48^{\mathrm{b}} \pm 0.34$ & $10.26^{\mathrm{b}} \pm 0.38$ \\
\hline
\end{tabular}

Values are means \pm standard errors

The means in a row with different superscripts differ significantly between the treatments $(\mathrm{P}<0.05)$ 
Fig.1 Dry matter intake (kg/day)

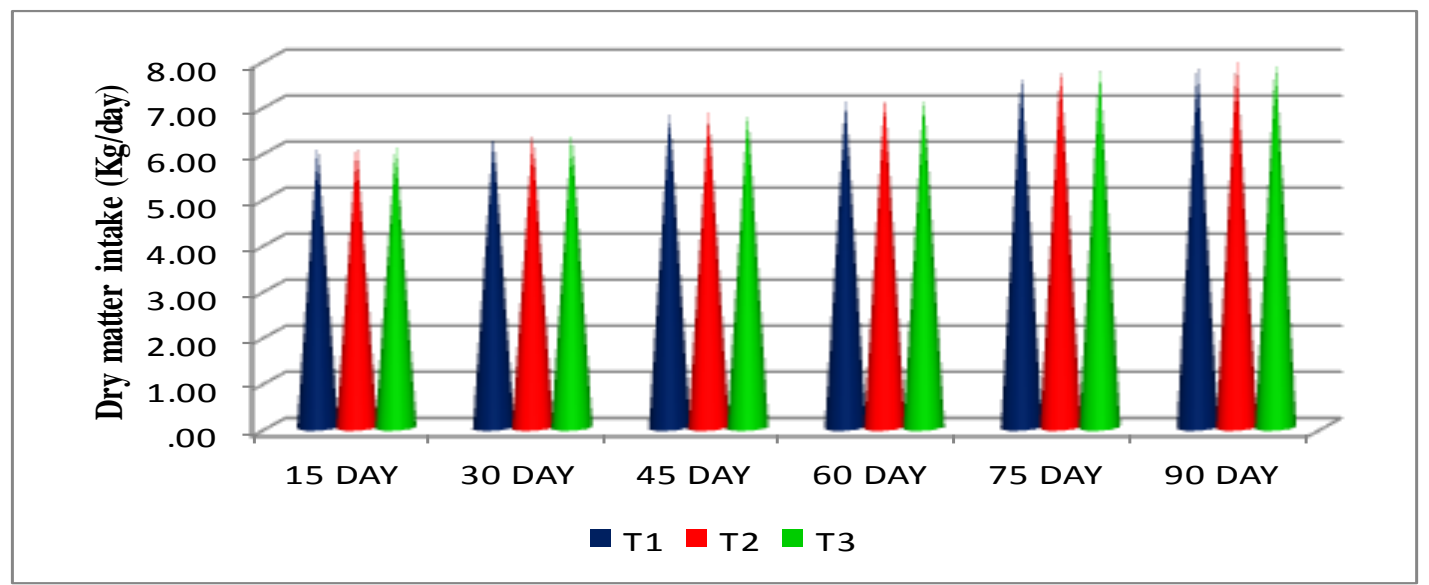

Fig.2 Average daily body weight gain (g)

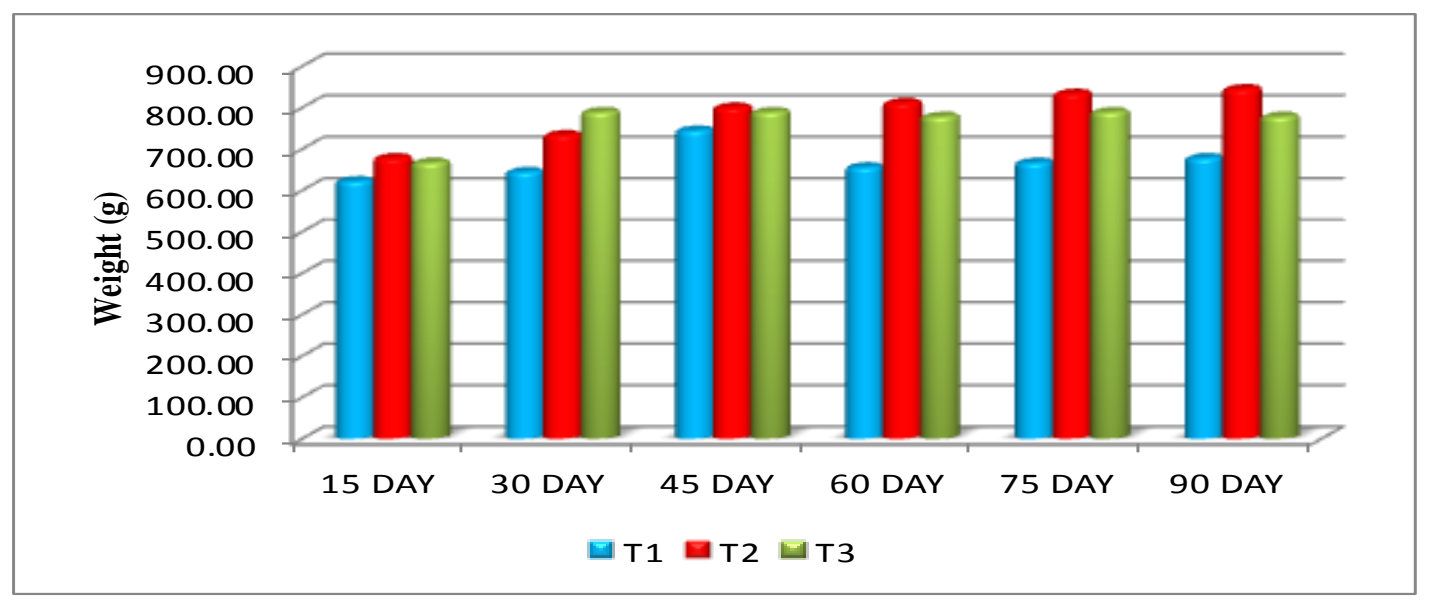

Fig.3 Feed conversion ratio

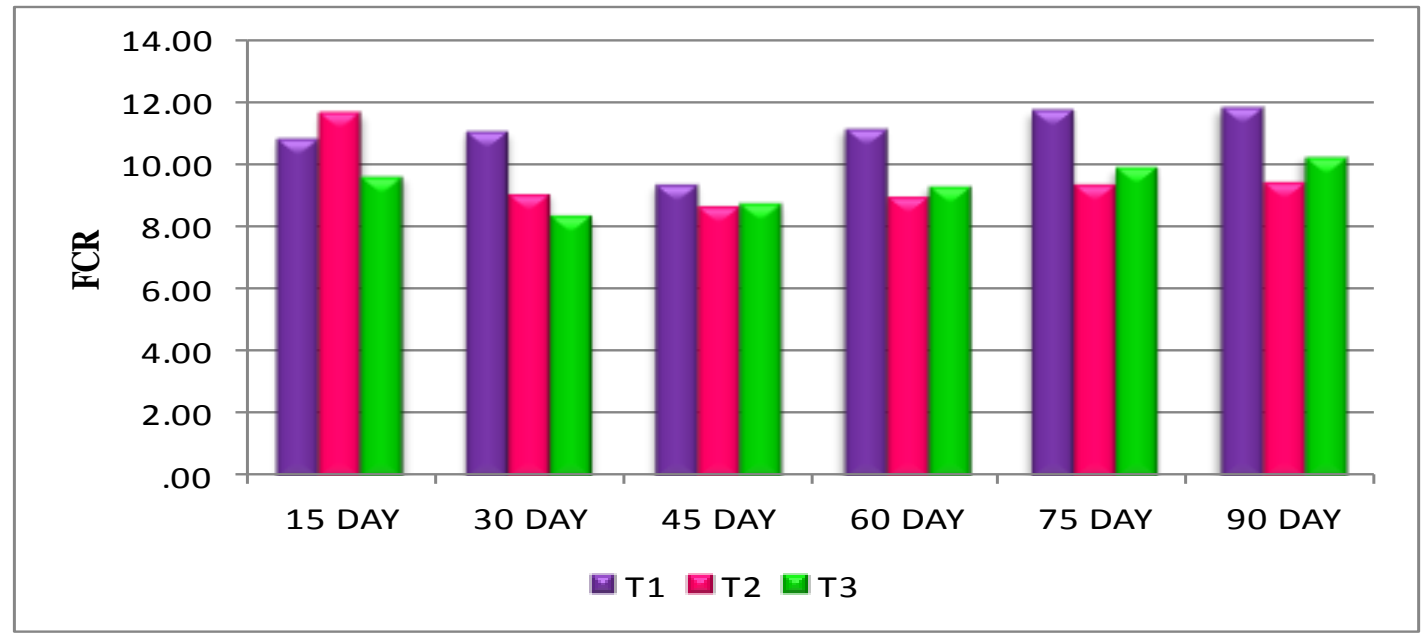


The data did not show any significant increase in average daily weight gain among the different treatments up to 45 days but after 60 days there was significantly higher $(\mathrm{P}<0.05)$ gain in $\mathrm{T}_{2}$ treatment which was similar to $\mathrm{T}_{3}$ as compared to control $\mathrm{T}_{1}$. The average daily gain then followed similar trend till the end of experiment. Average daily weight gains at the end of experiment, for the corresponding groups were 677.78, 844.44 and $777.78 \mathrm{~g} / \mathrm{d}$, respectively.

Overall, average daily body weight gain under three treatments during the whole experimental period was $668.51,783.33$ and $764.81 \mathrm{~g} / \mathrm{d}$, in $\mathrm{T}_{1}, \mathrm{~T}_{2}$ and $\mathrm{T}_{3}$ groups, respectively. The overall, average weight gain was significantly $(\mathrm{P}<0.05)$ higher in $\mathrm{T}_{2}$ and $\mathrm{T}_{3}$ treatments as compared to those of $\mathrm{T}_{1}$.

Zerbini and Polan (1985) and Davenport et al., (1990) reveal similar results that feeding fish meal as a source of protected amino acids significantly increased average daily weight gain in calves. Similarly Rocha et al., (1995) reported that group of Brahman bulls fed with fish meal had significantly higher average daily gain as compared to control group.

Alam et al., (2012), Ortigues et al., (1990) and Calzadilla et al., (1992) observed that daily weight gain of heifers was significantly higher when basal diet was supplemented with fish meal. Gajera et al., (2013) in the group of Jaffrabadi buffalo heifers and Sai et al., (2014) in the group of crossbred calves, reported higher daily weight gain in treatment group supplemented with bypass Methionine and Lysine in the ration over that of control group.

\section{Feed conversion ratio (FCR)}

Minimum requirement of nutrient per $\mathrm{kg}$ gain along with the optimum growth rate resulting into economic rearing of animals is a desirable feature of livestock production. For the calculation of FCR, feed intake per $\mathrm{kg}$ body weight gain was calculated. The average data for dry matter required per $\mathrm{kg}$ gain in weight at fortnightly interval have been presented in table 6 and with Figure 3.

After first fifteen days FCR values were $10.86,10.86$ and 9.63 in $\mathrm{T}_{1}$ (control), $\mathrm{T}_{2}$ and $\mathrm{T}_{3}$, respectively. The results did not show any significant difference in FCR values among the different treatments up to 45 days but after 60 days FCR values was significantly differ $(\mathrm{P}<0.05)$ in $\mathrm{T}_{2}$ and $\mathrm{T}_{3}$ treatments as compared to control $\mathrm{T}_{1}$. The FCR values then follow similar trend till the end of experiment.

The FCR values at the end of experiment, for $\mathrm{T}_{1}, \mathrm{~T}_{2}$ and $\mathrm{T}_{3}$ treatments was $11.83,9.48$ and 10.26 , respectively.

Present findings are in agreement with the previous findings of Sai et al., (2014) where they reported that percent feed efficiency in crossbred calves was higher $(\mathrm{P}<0.05)$ in treatment group supplemented with bypass Methionine and Lysine in the ration over that of control group. Yadav (1993) found that requirement of $\mathrm{DM}$ per $\mathrm{kg}$ gain was less by the female Murrah buffalo calves by feeding of yeast culture fortified with protected protein (Nutri-Sacc). Addition of fish meal (FM) to the diets of beef calves increased feed efficiency when compared to control diets (Davenport et al., 1990). Zinn and Owens, (1993) reported, increased feed efficiency by incorporation of FM in the ration of steers.

Present study suggested that feeding of fish meal and rumen protected Methionine and Lysine to Murrah buffalo heifers have significant effect on feed conversion ratio. The possible reason may be improved nutrient absorption, efficient gut micro-flora and better digestibility in fish meal and rumen protected Methionine and Lysine. 


\section{References}

Ahmed S., Gohar M., Khalique A., Ahmad N., Shahzad F., Azam B., Rahman A. and Khan M. I. (2016). Effect of Supplementation of Rumen Protected Lysine and Methionine on Production Performance, Milk and Blood Parameters of Early Lactating Nili-Ravi Buffaloes. Pakistan J. Zool., vol. 48(2), pp. 359-363.

Alam, M. S., Rashi, M. H., Uddin, M. E. and Asaduzzaman, M. (2012). Effect of supplementation of fish meal on growth and reproductive performance of crossbred heifers. J. Bangladesh Agril. Univ., 10(2): 261-266.

Ali C. S., Islam-ud-din, Sharif1, M., Nisa, M., Javaid, A., Hashmi N. and Sarwar M. (2009). Supplementation of Ruminally Protected Proteins and Amino Acids: Feed Consumption, Digestion and Performance of Cattle and Sheep International J. of Agric. \& Bio., 11(4): 477-482.

AOAC (2005). Official methods of analysis, $18^{\text {th }}$ edition. Association of official analytical chemists. Gaithersburg, Maryland, USA.

Blauwiekel, R., Xu, S. and Harrison, J. H. (1992). The use of cereal grains and byproduct feeds to meet the amino acid requirements of dairy cattle. In: Proc. 27th Pacific Northwest Animal Nutrition Conf. pp 225-236. Spokane, WA.

Calzadilla, O., Rattia, A. and Combellas, J. (1992). Nitroen supplementation of maize and sorghum silage for growing cattle. 1. Addition of fish meal. Revistade-la-facultad-de-Agronomia,Universidad-Central-de-Venezuela. 18:201.

Davenport, G. M., Boling, J. A. and Gay, N. (1990). Performance and plasma amino acids of growing calves fed corn silage supplemented with ground soybeans, fishmeal, and rumen-protected Lysine. J. Anim. Sci., 68: 3773-3779.

Duncan, D. B. (1955). Multiple range and multiple F tests. Biometrics. 11(1): 142.

Gajera, A. P., Dutta, K. S., Savsani, H. H., Parsana Vataliya, P. H., Sipai, S. H., Ribadiya, N. K. (2013). Effect of rumen protected Lysine, Methionine and fat on nutrients utilization in growing Jaffrabadi heifers. Indian J. of Ani. Nutrition 30(4): 351-357.

Hussein, H. S. and Jordan, R. M. (1991). Fish meal as a protein supplement in finishing lamb diets. J Anim. Sci., 69: 2115-2122.

Lall, S. P. (1991). Digestibility, metabolism and excretion of dietary phosphorus by fish. In: C. B. Cowey and C. Y. Cho (Eds), Proc, First Int symp on Nutritional Strategies in Management of Aquaculture Waste, University of Guelph, Canada. 275p.

Lara, A., Mendoza, G. D., Landois, L., Barcena, R., Saanchez, M. T., Rojo, R., Ayala, J. and Vaga, S., (2006). Milk production in Holstein cows using different levels of ruminaly protected Methionine. Livest. Sci., 105: 105-108.

Lee, C., Hristov, A. N., Cassidy, T. W., Heyler, K. S., Lapierre, H., Varga, G. A., Veth, M. J., Patton, R. A. and Parys, C. (2012). Rumen-protected Lysine, Methionine, and histidine increase milk protein yield in dairy cows fed a metabolizable protein-deficient diet. $J$. Dairy Sci., 95: 6042-6056.

Ortigues, I., Smith, T., Gill, M., Cammell, S. B. and Yarrow, N. W. (1990). The effect of fishmeal supplementation of a straw-based diet on growth and calorimetric efficiency of growth in heifers. Br J Nutr., 64(3):639-51.

Ranjhan, S. K. (1998). Nutritional Requirement of Livestock and Poultry. 
$2^{\text {nd }}$ Revised Edn., Indian Council of Agricultural Research. Krishi Anusandhan Bhavan, Pusa, New Delhi.

Rocha, A., Carpena, M., Triplett, B., Forrest, D. W. and Randel, R. D. (1995). Effect of ruminally undegradable protein from fish meal on growth and reproduction of peripuberal brahman bulls. J. Anim. Sci., 73: 947-953.

Sai, S., Thakur, S. S., Kewalramani, N., Chaurasia, M. (2014). Effect of Supplementation of Rumen Protected Methionine plus Lysine on Growth Performance, Nutrient Utilization and Blood Metabolites in Calves. Indian J. of Animal Nutrition: 31(1): 1-7.

Snedecor, G. W. and Cochran, W. G. (1994). Statistical Methode. $8^{\text {th }}$ edn., Oxford and IBH Publishing Co., New Delhi.
Socha, M. T., Putnam, D. E., Garthwaite, B. D., Whitehouse, N. L. and Kierstead, N. A. (2005). Amino acid supply of Preand Postpartum dairy cows with Rumen protected Methionine and Lysine. $J$. Dairy Sci., 88: 1113-1126.

Yadav, M. S. (1993). Effect of commercial yeast culture supplementation in the diet of female buffalo calves on growth and feed conversion efficiency. PhD Thesis, Haryana Agril. Univ., Hisar.

Zerbini, E. and Polan, C. E. (1985). Protein sources evaluated for ruminating Holstein calves. J. Dairy Sci., 68: 14161424.

Zinn, R. A. and Owens, F. N. (1993). Ruminal escape protein for live weight fed lot calves. J. Anim. Sci., 71:1677.

\section{How to cite this article:}

Ravi Kumar, Dipankar Kar, Deepak Kumar, Vikramjeet Singh and Sajjan Sihag. 2018. Effect of Rumen Protected Amino Acids and Fish Meal on Feed Conversion Ratio of Murrah Buffalo Heifers. Int.J.Curr.Microbiol.App.Sci. 7(03): 2587-2595. doi: https://doi.org/10.20546/ijcmas.2018.703.299 